\title{
Why and how protein aggregation has to be studied in vivo
}

\author{
Diletta Ami ${ }^{1,2}$, Antonino Natalello ${ }^{1}$, Marina Lotti ${ }^{1}$ and Silvia Maria Doglia ${ }^{1,2^{*}}$
}

\begin{abstract}
The understanding of protein aggregation is a central issue in different fields of protein science, from the heterologous protein production in biotechnology to amyloid aggregation in several neurodegenerative and systemic diseases. To this goal, it became more and more evident the crucial relevance of studying protein aggregation in the complex cellular environment, since it allows to take into account the cellular components affecting protein aggregation, such as chaperones, proteases, and molecular crowding. Here, we discuss the use of several biochemical and biophysical approaches that can be employed to monitor protein aggregation within intact cells, focusing in particular on bacteria that are widely employed as microbial cell factories.
\end{abstract}

Keywords: Amyloids, Inclusion bodies, Intact cells, Protein aggregation, Spectroscopy

Protein aggregation is a relevant process in different fields of biomedicine and biotechnology. Indeed, many diseases are associated to the deposition of amyloid aggregates [1], while the formation of inclusion bodies (IBs) often occurs during the production of heterologous proteins [2,3]. In particular, bacterial IBs, for a long time considered a bottleneck during recombinant protein production, have recently gained attention $[4,5]$ as a precious source of active recombinant proteins [6-8], as well as a model system for amyloid studies [9-15]. Moreover, the peculiar structural properties of IBs and the observation that the aggregated proteins can retain their activity opened the possibility to use IBs in bio-catalysis [16], regenerative medicine [17], and in the controlled delivery of therapeutic polypeptides $[18,19]$.

Protein misfolding and aggregation have been extensively studied in the test tube, therefore under conditions that are far from the physiological and pathological ones. For this reason, in order to take into account the complexity of the cellular environment that plays a crucial role in tuning protein aggregation [20], it is important to extend these investigations to intact cells [21].

In this commentary we focalized our attention on the different approaches that allow to monitor protein

\footnotetext{
* Correspondence: silviamaria.doglia@unimib.it

'Department of Biotechnology and Biosciences, University of Milano-Bicocca, Piazza della Scienza 2, 20126, Milano, Italy

2Department of Physics "G. Occhialini", University of Milano-Bicocca, Piazza della Scienza 3, 20126, Milano, Italy
}

\section{Biomed Central}

(c) 2013 Ami et al.; licensee BioMed Central Ltd. This is an Open Access article distributed under the terms of the Creative Commons Attribution License (http://creativecommons.org/licenses/by/2.0), which permits unrestricted use, distribution, and reproduction in any medium, provided the original work is properly cited. aggregation within bacterial cells (Table 1). We should note that most of these approaches have been successfully applied to monitor protein aggregation also within intact eukaryotic cells, including yeasts and mammals.

Among the most employed methods to study protein aggregation in situ, some are based on the fluorescence detection of genetically encoded fusion tags, or of conformational-sensitive fluorescent dyes. In the first case, one of the most important tools is represented by the green fluorescent protein (GFP) and its variants, such as the yellow, the blue and the red, used to obtain fluorescent chimera-proteins, easily detectable by fluorescence microscopy and flow-cytometry.

This approach has been applied, for instance, to investigate the presence of functional proteins embedded in bacterial IBs [22-24]. Interestingly, in recent works it has been observed that the fusion of self-assembling or surfactant-like peptides to different proteins makes it possible to obtain active IBs, whose formation was detected in vivo monitoring the fluorescence of GFP - taken as a model system - fused to the peptide. Indeed, the bacterial cell images, obtained by confocal microscopy, showed a diffuse fluorescence when GFP was expressed alone, in a soluble form. When, instead, the GFP was expressed fused to the self-assembling or surfactant-like peptide, the fluorescence appeared localized in the cell, indicating the formation of active IBs $[23,24]$. Moreover the use of GFP tag as a reporter for corrected folding has been employed 
Table 1 Methods for the study of protein aggregation in intact cells

\begin{tabular}{|c|c|c|c|}
\hline \multicolumn{2}{|c|}{ Approach } & Measurement & Application examples \\
\hline \multicolumn{4}{|c|}{$\star$ Genetically encoded fusion tags } \\
\hline $\begin{array}{l}\checkmark \text { Fusion of the target } \\
\text { polypeptide with a fluorescent } \\
\text { protein or an enzyme }\end{array}$ & $\begin{array}{l}\text { Reduction of fluorescence or of enzymatic } \\
\text { activity after aggregation; detection of } \\
\text { functional polypeptides within active IBs }\end{array}$ & \multirow{2}{*}{$\begin{array}{l}\text { Bulk cell fluorescence; } \\
\text { fluorescence } \\
\text { microscopy; flow } \\
\text { cytometry; enzymatic } \\
\text { activity }\end{array}$} & \multirow{2}{*}{$\begin{array}{l}\text { Monitoring of protein aggregation } \\
\text { within intact cells [31]; localization of } \\
\text { functional polypeptides within IBs [22]; } \\
\text { formation of active IBs [16,23,24]; } \\
\text { screening of aggregation inhibitors [26 }\end{array}$} \\
\hline $\begin{array}{c}\checkmark \text { Fusion of the target } \\
\text { polypeptide with the tetra-Cys } \\
\text { tag }\end{array}$ & $\begin{array}{l}\text { Formation of hyperfluorescent aggregates } \\
\text { in presence of FIAsH }\end{array}$ & & \\
\hline \multicolumn{4}{|c|}{$\%$ Conformational sensitive dyes } \\
\hline$\checkmark$ Thioflavin-S & $\begin{array}{l}\text { Th-S fluorescence reports on amyloid-like } \\
\text { structure of the protein aggregates }\end{array}$ & $\begin{array}{l}\text { Bulk cell fluorescence; } \\
\text { fluorescence } \\
\text { microscopy; flow } \\
\text { cytometry }\end{array}$ & $\begin{array}{l}\text { Detection of amyloid-like aggregates } \\
\text { within intact cells [32] }\end{array}$ \\
\hline \multicolumn{4}{|c|}{$\%$ Direct spectroscopic detection of structural properties } \\
\hline$\checkmark$ FTIR & $\begin{array}{l}\text { Monitoring of intermolecular } \beta \text {-sheet } \\
\text { structures in IBs }\end{array}$ & $\begin{array}{l}\text { Label-free intact cell } \\
\text { (micro)spectroscopy }\end{array}$ & $\begin{array}{l}\text { Monitoring of protein aggregation } \\
\text { whithin intact cells }[35,39]\end{array}$ \\
\hline$\checkmark$ NMR & $\begin{array}{l}\text { Detailed structural information of the } \\
\text { protein embedded within IBs }\end{array}$ & $\begin{array}{l}\text { Solid-state NMR of } \\
\text { whole cells }\end{array}$ & Detection of native-like structures [43] \\
\hline \multicolumn{4}{|c|}{$*$ Aggregation sensitive reporters } \\
\hline $\begin{array}{l}\checkmark \text { Reporter protein under an } \\
\text { aggregation sensitive promoter }\end{array}$ & $\begin{array}{l}\text { Protein aggregation induces the } \\
\text { expression of the reporter protein. The } \\
\text { measured fluorescence or enzymatic } \\
\text { activity of the reporter protein is related } \\
\text { to the level of aggregation within cells }\end{array}$ & $\begin{array}{l}\text { Enzymatic activity; } \\
\text { fluorescence }\end{array}$ & $\begin{array}{l}\text { Monitoring of protein aggregation } \\
\text { within intact cells }[37,45]\end{array}$ \\
\hline
\end{tabular}

for the screening of $A \beta$ mutations and chemical compounds able to tune the aggregation propensity of the peptide. In particular, it should be noted that the fluorescence of the fusion protein in intact cells was found to be inversely correlated with the aggregation of the $A \beta-G F P$ fusion protein [25-27].

Noteworthy, the fusion with fluorescent proteins has been also employed to investigate the mechanism of protein deposition at the single cell level [28] and the specificity of protein-protein interaction during in vivo protein deposition. To this aim, for instance, Morell and colleagues performed Förster resonance energy transfer (FRET) experiments in prokaryotic cells, labeling two self-aggregating proteins, the A $\beta 42$ amyloid peptide and the VP1 capsid protein, with proper fluorescent protein variants [29]. In this way, the specificity of protein deposition was indicated by a higher FRET efficiency, observed when the two dyes were fused to the same poly peptide, rather than to the different ones.

Other applications based on fluorescence analysis to detect, in real time, protein aggregation in vivo include the labeling of the target protein with a tetra-cysteine sequence (Cys-Cys-X-Y-Cys-Cys), which specifically binds the bis-arsenical fluorescein-based dye (FIAsH) [30]. This smart approach enables to monitor the formation of hyperfluorescent aggregates within intact cells, by simply detecting the bulk cell fluorescence or by fluorescence microscopy [30,31].
Protein aggregation can be also studied in vivo using conformational-sensitive dyes, such as the thioflavin-S (Th-S), whose fluorescence spectroscopic features change upon interaction with amyloid aggregates. As recently reported in the literature, the capability of Th-S to be internalized in bacterial cells has been exploited to detect intracellular amyloid-like aggregates by fluorescence spectroscopy, microscopy and flow cytometry. Interestingly, this approach can represent a new tool to screen the effects of amyloid inhibitors in an intracellular environment [32].

Among the spectroscopic techniques that allow to study protein aggregation in intact cells, Fourier transform infrared (FTIR) spectroscopy offers the advantage to be a label-free tool. In particular, the detection of protein aggregates is based on the presence of a specific marker band due to the formation of intermolecular $\beta$ sheet structures [33,34]. Following this approach, it has been possible to monitor the kinetics of IB formation within growing $E$. coli cells, under different expression conditions [35]. Interestingly, since the infrared response of an intact cell represents a chemical fingerprint of its main biomolecules [36], the IR spectral analysis makes it possible to obtain also complementary information on cell processes that accompany protein aggregation, including for instance the effects on cell membranes [37].

Moreover, the IR study of extracted IBs allows to obtain important information on the structural properties 
of the aggregated protein [34,38,39], and in particular to detect the presence of native-like secondary structures of the proteins within IBs. For these reasons, the IR approach is a useful tool to identify the best conditions that enable to modulate not only the level of protein aggregation, but also the quality of the protein inside the IBs.

A more detailed structural information of the protein embedded within IBs can be obtained by nuclear magnetic resonance (NMR) spectroscopy, a technique that was applied not only to characterize isolated [40-42] IBs, but also IBs within cells [43]. For instance, in the pioneering work of Curtis-Fiske and colleagues, solid state NMR was applied to study whole bacterial cells expressing the HA2 subunit of the influenza virus hemagglutinin protein in form of IBs. In this way, labeling the backbone carbonyl and nitrogen $\left({ }^{13} \mathrm{CO}\right.$ and $\left.{ }^{15} \mathrm{~N}\right)$ for each amino-acid, it has been possible to identify the localization of native-like $\alpha$-helices of the protein functional domain, and to reveal also the protein conformational heterogeneity within IBs [43].

Finally, the evaluation of protein aggregation within intact cells could be also tackled by a biochemical approach based on the use of gene promoters specifically triggered by protein misfolding and aggregation [44-46]. For instance, the expression of the $\beta$-galactosidase reporter under the control of the chaperone IbpB promoter, specifically activated by misfolded proteins, allowed the estimation of protein aggregation accumulated inside the cell [45]. By this approach, together with complementary biochemical and biophysical analyses, it has been studied the recombinant expression of the glutathione-S-transferase and its fusion with GFP, whose aggregation can be tuned by changing the expression conditions. Interestingly, it has been found that in this model system misfolded proteins and soluble aggregates - but not the soluble native protein nor IBs - lead to a significant reorganization of the cell membranes and of the host protein expression [37], a relevant result in the proteotoxicity context.

\section{Conclusions}

We underline here the need to extend the study of protein aggregation in an intracellular environment in the presence of factors - such as chaperones, proteases, and the molecular crowding - that can affect in a crucial way the aggregation process in vivo.

Indeed, it will be necessary to complement studies in the test tube with those in intact cells, not only to reach a better comprehension of the mechanisms underlying protein aggregation, but also to identify the factors that can modulate aggregation, such as protein expression conditions, mutations, and the effects of chemical compounds.

In this view, it will be highly desirable to further develop methods that might enable investigations in intact cells, not only for the basic understanding of aggregation in situ, but also for applications in recombinant protein productions and for the screening of compounds inhibiting aggregation, a relevant issue in medical therapies.

\section{Abbreviations}

FIAsH: Bis-arsenical fluorescein-based dye; FRET: Förster resonance energy transfer; FTIR: Fourier transform infrared; GFP: Green fluorescent protein; IBs: Inclusion bodies; NMR: Nuclear magnetic resonance; Th-S: Thioflavin-S.

\section{Competing interests}

The authors declare that they have no competing interests.

\section{Acknowledgements}

D.A. acknowledges a postdoctoral fellowship of the University of MilanoBicocca.

Received: 4 February 2013 Accepted: 7 February 2013

Published: 15 February 2013

\section{References}

1. Chiti F, Dobson CM: Protein misfolding, functional amyloid, and human disease. Annu Rev Biochem 2006, 75:333-366.

2. Marston FAO: The purification of eukaryotic polypeptides synthesized in escherichia-coli. Biochem J 1986, 240:1-12.

3. Villaverde $A$, Carrio MM: Protein aggregation in recombinant bacteria: biological role of inclusion bodies. Biotechnol Lett 2003, 25:1385-1395.

4. Garcia-Fruitos E: Inclusion bodies: a new concept. Microb Cell Fact 2010, 9:80.

5. Gatti-Lafranconi P, Natalello A, Ami D, Doglia SM, Lotti M: Concepts and tools to exploit the potential of bacterial inclusion bodies in protein science and biotechnology. FEBS J 2011, 278:2408-2418.

6. Patra AK, Mukhopadhyay R, Mukhija R, Krishnan A, Garg LC, Panda AK: Optimization of inclusion body solubilization and renaturation of recombinant human growth hormone from Escherichia coli. Protein Expr Purif 2000, 18:182-192.

7. Peternel S, Grdadolnik J, Gaberc-Porekar V, Komel R: Engineering inclusion bodies for non denaturing extraction of functional proteins. Microb Cell Fact 2008, 7:34.

8. Peternel $\mathrm{S}$, Komel $\mathrm{R}$ : Isolation of biologically active nanomaterial (inclusion bodies) from bacterial cells. Microb Cell Fact 2010, 9:66.

9. Carrio M, Gonzalez-Montalban N, Vera A, Villaverde A, Ventura S: Amyloidlike properties of bacterial inclusion bodies. J Mol Biol 2005, 347:1025-1037.

10. Sabate R, Espargaro A, Saupe SJ, Ventura S: Characterization of the amyloid bacterial inclusion bodies of the HET-s fungal prion. Microb Cell Fact 2009, 8:56.

11. Garcia-Fruitos E, Sabate R, de Groot NS, Villaverde A, Ventura S: Biological role of bacterial inclusion bodies: a model for amyloid aggregation. FEBS J 2011, 278:2419-2427.

12. Villar-Pique A, Ventura S: Modeling amyloids in bacteria. Microb Cell Fact 2012, 11:166.

13. Espargaro A, Villar-Pique A, Sabate R, Ventura S: Yeast prions form infectious amyloid inclusion bodies in bacteria. Microb Cell Fact 2012, 11:89.

14. Villar-Pique A, Espargaro A, Sabate R, de Groot N, Ventura S: Using bacterial inclusion bodies to screen for amyloid aggregation inhibitors. Microb Cell Fact 2012, 11:55

15. Invernizzi G, Aprile FA, Natalello A, Ghisleni A, Penco A, Relini A, Doglia SM, Tortora $P$, Regonesi ME: The relationship between aggregation and toxicity of polyglutamine-containing ataxin-3 in the intracellular environment of escherichia coli. PLoS One 2012, 7:e51890.

16. Garcia-Fruitos E, Gonzalez-Montalban N, Morell M, Vera A, Ferraz R, Aris A, Ventura S, Villaverde A: Aggregation as bacterial inclusion bodies does not imply inactivation of enzymes and fluorescent proteins. Microb Cell Fact 2005, 4:27.

17. Garcia-Fruitos E, Seras-Franzoso J, Vazquez E, Villaverde A: Tunable geometry of bacterial inclusion bodies as substrate materials for tissue engineering. Nanotechnology 2010, 21:205101. 
18. Liovic M, Ozir M, Zavec A, Peternel S, Komel R, Zupancic T: Inclusion bodies as potential vehicles for recombinant protein delivery into epithelial cells. Microb Cell Fact 2012, 11:67.

19. Villaverde A, Garcia-Fruitos E, Rinas U, Seras-Franzoso J, Kosoy A, Corchero $J$, Vazquez E: Packaging protein drugs as bacterial inclusion bodies for therapeutic applications. Microb Cell Fact 2012, 11:76.

20. Gasser B, Saloheimo M, Rinas U, Dragosits M, Rodriguez-Carmona E, Baumann K, Giuliani M, Parrilli E, Branduardi P, Lang C, et al: Protein folding and conformational stress in microbial cells producing recombinant proteins: a host comparative overview. Microb Cell Fact 2008, 7:11.

21. Ignatova Z: Monitoring protein stability in vivo. Microb Cell Fact 2005, 4:23.

22. Garcia-Fruitos E, Aris A, Villaverde A: Localization of functional polypeptides in bacterial inclusion bodies. Appl Environ Microbiol 2007, 73:289-294.

23. Wu W, Xing L, Zhou B, Lin Z: Active protein aggregates induced by terminally attached self-assembling peptide ELK16 in Escherichia coli. Microb Cell Fact 2011, 10:9.

24. Zhou B, Xing L, Wu W, Zhang X-E, Lin Z: Small surfactant-like peptides can drive soluble proteins into active aggregates. Microb Cell Fact 2012, 11:10.

25. Kim W, Hecht MH: Sequence determinants of enhanced amyloidogenicity of Alzheimer A beta 42 peptide relative to A beta 40. J Biol Chem 2005, 280:35069-35076.

26. Kim W, Kim Y, Min J, Kim DJ, Chang YT, Hecht MH: A high-throughput screen for compounds that inhibit aggregation of the Alzheimer's peptide. ACS Chem Biol 2006, 1:461-469.

27. Kim W, Hecht MH: Mutations enhance the aggregation propensity of the Alzheimer's A beta peptide. J Mol Biol 2008, 377:565-574.

28. Zhao Y, He W, Liu WF, Liu CC, Feng LK, Sun L, Yan YB, Hang HY: Two distinct states of escherichia coli cells that overexpress recombinant heterogeneous beta-galactosidase. J Biol Chem 2012, 287:9259-9268.

29. Morell M, Bravo R, Espargaro A, Sisquella X, Aviles FX, Fernandez-Busquets X, Ventura S: Inclusion bodies: Specificity in their aggregation process and amyloid-like structure. Biochim Biophys Acta 2008, 1783:1815-1825.

30. Ignatova Z, Gierasch LM: Monitoring protein stability and aggregation in vivo by real-time fluorescent labeling. Proc Natl Acad Sci USA 2004, 101:523-528.

31. Ignatova Z, Gierasch LM: A Fluorescent Window Into Protein Folding and Aggregation in Cells. In Biophysical Tools for Biologists, Vol 2: In Vivo Techniques, Volume 89. Edited by Correia JJ, Detrich HW. San Diego: Elsevier Academic Press Inc; 2008:59-70. Methods in Cell Biology].

32. Espargaro A, Sabate R, Ventura S: Thioflavin-S staining coupled to flow cytometry. A screening tool to detect in vivo protein aggregation. Mol Biosyst 2012, 8:2839-2844.

33. Ami D, Bonecchi L, Cali S, Orsini G, Tonon G, Doglia SM: FT-IR study of heterologous protein expression in recombinant Escherichia coli strains. Biochim Biophys Acta 2003, 1624:6-10.

34. Ami D, Natalello A, Taylor G, Tonon G, Doglia SM: Structural analysis of protein inclusion bodies by Fourier transform infrared microspectroscopy. Biochim Biophys Acta 2006, 1764:793-799.

35. Ami D, Natalello A, Gatti-Lafranconi P, Lotti M, Doglia SM: Kinetics of inclusion body formation studied in intact cells by FT-IR spectroscopy. FEBS Lett 2005, 579:3433-3436.

36. Ami D, Natalello A, Doglia SM: Fourier transform infrared microspectroscopy of complex biological systems: From intact cells to whole organisms. In Intrinsically Disordered Protein Analysis: Volume 1, Methods and Experimental Tools, Volume 895. Edited by Uversky VN, Dunker AK. New York: Humana Press; 2012:85-100. Methods in Molecular Biology.

37. Ami D, Natalello A, Schultz T, Gatti-Lafranconi P, Lotti M, Doglia SM, de Marco A: Effects of recombinant protein misfolding and aggregation on bacterial membranes. Biochim Biophys Acta 2009, 1794:263-269.

38. Oberg K, Chrunyk BA, Wetzel R, Fink AL: Native-like secondary structure in interleukin-1-beta inclusion-bodies by attenuated total reflectance ftir. Biochemistry 1994, 33:2628-2634.

39. Doglia SM, Ami D, Natalello A, Gatti-Lafranconi P, Lotti M: Fourier transform infrared spectroscopy analysis of the conformational quality of recombinant proteins within inclusion bodies. Biotechnol J 2008, 3:193-201.

40. Wang L, Maji SK, Sawaya MR, Eisenberg D, Riek R: Bacterial inclusion bodies contain amyloid-like structure. PLOS Biol 2008, 6:e195.

41. Wasmer C, Benkemoun L, Sabate R, Steinmetz MO, Coulary-Salin B, Wang L, Riek R, Saupe SJ, Meier BH: Solid-State NMR Spectroscopy Reveals that E. coli Inclusion Bodies of HET-s(218-289) are Amyloids. Angew Chem Int Ed 2009, 48:4858-4860.
42. Wang L, Schubert D, Sawaya MR, Eisenberg D, Riek R: Multidimensional structure-activity relationship of a protein in its aggregated states. Angew Chem Int Ed 2010, 49:3904-3908.

43. Curtis-Fisk J, Spencer RM, Weliky DP: Native conformation at specific residues in recombinant inclusion body protein in whole cells determined with solid-state NMR spectroscopy. J Am Chem Soc 2008, 130:12568-12569.

44. Lesley SA, Graziano J, Cho CY, Knuth MW, Klock HE: Gene expression response to misfolded protein as a screen for soluble recombinant protein. Protein Eng 2002, 15:153-160.

45. Schultz $T$, Martinez $L$, de Marco A: The evaluation of the factors that cause aggregation during recombinant expression in $\mathrm{E}$. coli is simplified by the employment of an aggregation-sensitive reporter. Microb Cell Fact 2006, 5:28.

46. Kraft M, Knüpfer U, Wenderoth R, Pietschmann P, Hock B, Horn U: An online monitoring system based on a synthetic sigma32-dependent tandem promoter for visualization of insoluble proteins in the cytoplasm of Escherichia coli. Appl Microbiol Biotechnol 2007, 75:397-406.

doi:10.1186/1475-2859-12-17

Cite this article as: Ami et al:: Why and how protein aggregation has to be studied in vivo. Microbial Cell Factories 2013 12:17.

\section{Submit your next manuscript to BioMed Central and take full advantage of:}

- Convenient online submission

- Thorough peer review

- No space constraints or color figure charges

- Immediate publication on acceptance

- Inclusion in PubMed, CAS, Scopus and Google Scholar

- Research which is freely available for redistribution

Submit your manuscript at www.biomedcentral.com/submit
C) Biomed Central 